ARTIKEL PENELITIAN

\title{
PEMERIKSAAN DAYA HAMBAT EKTRAK METANOL DAUN TRISTANIA SUBAURICULATA KING TERHADAP PERTUMBUHAN KUMAN PSEUDOMONAS AERUGINOSA DAN STAPHYLOCOCCUS AUREUS
}

\author{
Yustini Alioes, ${ }^{1}$ Benni Raymond ${ }^{2}$ \\ 1. Bagian Biokimia Fakultas Kedokteran Universitas Andalas \\ 2. Mahasiswa Fakultas Kedokteran Universitas Andalas \\ E-mail : rafhikii@gmail.com
}

\begin{abstract}
Abstrak
Tristania subauriculata King dikenal oleh penduduk sekitar Kelok Sembilan, Payakumbuh sebagai obat untuk mengobati penyakit kulit. Diduga Tristania subauriculata King mengandung suatu senyawa bioaktif yang bersifat sebagai anti bakteri.

Untuk melihat efektifitas ekstrak metanol daun Tristania subauriculata King dalam menghambat pertumbuhan kuman Pseudomonas aeruginosa dan Staphylococcus aureus, telah dilakukan penelitian secara invitro dengan menggunakan metode difusi agar, pengamatan dilakukan dengan mengukur diameter daerah hambat yang terbentuk pada agar.

Dari penelitian didapatkan adanya daya hambat ekstrak metanol daun Tristania subauriculata King $15 \% \mathrm{~b} / \mathrm{v}$ dalam menghambat pertumbuhan kuman Pseudomonas aeruginosa dan Staphylococcus aureus. Daya hambat ini meningkat pada konsentrasi $30 \% \mathrm{~b} / \mathrm{v}, 45 \% \mathrm{~b} / \mathrm{v}$, dan daya hambat terbesar pada konsentrasi $60 \% \mathrm{~b} / \mathrm{v}$ yang terlihat dengan semakin besarnya diameter daerah bebas kuman yang dihasilkan.
\end{abstract}

Kata kunci : Ekstrak Metanol daun Tristania subauriculata King, Diameter hambat, Pseudomonas aeruginosa dan Staphylococcus aureus

\begin{abstract}
Tristania subauriculata King has been known by the people of Kelok Sembilan, Payakumbuh as the medicine to cure dermatopathy. It is thought that Tristania subauriculata King contains a bioactive constituent which acts as anti bacteria.

To figure the effects of methanol extract of Tristania subauriculata King in holding the growth of Pseudomonas aeruginosa and Staphylococcus aureus, an invitro observation has been done using difusion agar method. The observation was done by measuring the diameter of inhibition area that has been formed.

From the observation, it is found that there is inhibition capacity of methanol extract of Tristania subauriculata King $15 \%$ b/v in holding the growth of
\end{abstract}


Pseudomonas aeruginosa and Staphylococcus aureus. This inhibition capacity increase on the concentration of $30 \% \mathrm{~b} / \mathrm{v}, 45 \% \mathrm{~b} / \mathrm{v}$, and the biggest inhibition capacity is on the concentration of $60 \% \mathrm{~b} / \mathrm{v}$ which can be seen with the increase of inhibition zone.

Key word: Folium Tristania subauriculata King extract metanol, Diameter hambat, Pseudomonas aeruginosa and Staphylococcus aureus 


\section{PENDAHULUAN}

Sumatera Barat merupakan daerah yang subur dan kaya dengan berbagai jenis tumbuhan, dimana sebagian tumbuhan tersebut telah digunakan oleh penduduk sebagai bahan obat tradisional terutama didasarkan pada pengalaman perorangan dan turun temurun yang belum dicatat dengan baik. ${ }^{(1)}$ Berdasarkan survei yang telah dilakukan oleh Arbain dan kawankawan semenjak tahun 1982, berhasil di inventarisir dan di data lebih dari 7500 tumbuhan Sumatera yang berbeda dan kebanyakan mempunyai nilai tradisional dan juga memberikan hasil tes yang positif untuk satu atau lebih kelompok metabolit sekunder tertentu dan dari 200 tumbuhan yang telah dikumpulkan telah di evaluasi aktifitas biologisnya seperti antibakteri dan anti jamur. $^{(2)}$

Penelitian terhadap metabolit sekunder yang dihasilkan tumbuhan mempunyai arti yang sangat penting,karena banyak penyakit yang menyerang manusia, hewan atau tumbuhan, dimana sangat sulit dirancang molekul-molekul yang aktif dan potensial sebagai obat untuk menanganinya. Akhir-akhir ini ahli kimia telah memusatkan perhatiannya untuk mengisolasi dan menentukan struktur serta menguji aktifitas biologis dari metabolit sekunder yang dihasilkan oleh tumbuhan tersebut. ${ }^{(3)}$

Tristania subauriculata atau lebih dikenal oleh penduduk sekitar di daerah Kelok Sembilan, Payakumbuh, Sumbar, dengan nama kalek salusuah adalah sejenis tumbuhan yang digunakan untuk melancarkan proses kelahiran dan mengobati penyakit kulit dengan cara mengoleskan rajahan daun Tristania subauriculata.

Penyakit kulit yang ada di Indonesia selain disebabkan oleh gangguan gizi juga akibat faktor lingkungan seperti; iklim yang panas, kelembaban, jamur, bakteri serta kebersihan tubuh sendiri. Kemajuan dalam penanggulangi penyakit kulit juga tergantung pada penyediaan air bersih yang cukup di sekitar tempat tinggal mereka. Sebagian besar bakter yang banyak menginfeksi kulit adalah jenis Staphilococcus. ${ }^{(4)}$

Infeksi oleh Staphilococcus sering oleh jenis Staphilococcus aureus, dimana dapat menyebabkan frunkel atau abses yang merupakan infeksi kulit menular. Penyebaran infeksi ini dapat dari manusia ke manusia lainnya atau dari binatang ke manusia melalui tetesan air ludah, kontak lesi kulit serta dapat melalui makanan atau minuman yang terkontaminasi. ${ }^{(5,7)}$

Bakteri lain yang dapat menyebabkan infeksi kulit adalah Pseudomonas aeruginosa yang dapat menimbulkan infeksi pada luka dan luka bakar dimana bersifat invasif dan toksigenik, menimbulkan infeksi bila fungsi pertahanan tubuh abnormal dan merupakan patogen nosokomial terpenting. ${ }^{(6)}$

Mengingat sangat pentingnya menelusuri tentang khasiat suatu tumbuhan apalagi tumbuhan Tristania subauriculata belum pernah diteliti lagi, maka peneliti tertarik untuk meakukan ekstraksi metanol dari daun Tristania subauriculata yang bersifat sebagai antibakteri dan menguji potensi antibakterinya secara invivo terhadap Staphilococcus aureus dan Pseudomonas aeruginosa dengan metode cakram.

\section{METODE PENELITIAN}

Penelitian ini bersifat eksperimental dengan menggunakan pola faktorial dalam Rancangan Acak Lengkap (RAL), dengan 3 kali pengulangan. Sebagai faktor disini adalah jenis bakteri dan konsentrasi 
EKTRAK METANOL DAUN TRISTANIA SUBAURICULATA KING TERHADAP PERTUMBUHAN KUMAN PSEUDOMONAS AERUGINOSA DAN STAPHYLOCOCCUS AUREUS

ekstrak metanol dari daun Tristania subauriculata. Penelitian ini dilakukan didaerah Kelok Sembilan Payakumbuh, Sumbar untuk mengambil sampel daun dan kemudian sampel diekstraksi di Laboratorium Organik FMIPA Unand dan seterusnya dilakukan pemeriksaan bakterinya di Laboratorium Mikrobiologi Fakultas Kedokteran Universitas Andalas.

Variabel yang dilakukan adalah Variabel bebas : Jenis bakteri Pseudomonas aeruginosa dan Staphylococcus aureus serta konsentrasi ekstrak $15 \%$ b/v, 30\% b/v, $45 \%$ b/v, $60 \% \mathrm{~b} / \mathrm{v}$ sedangkan Variabel tergantung : diameter daerah bebas bakteri.

\section{HASIL PENELITIAN}

Penelitian ini telah dilakukan di Laboratorium Kimia Organik FMIPA dan laboratorium Mikrobiologi Fakultas Kedokteran Universitas Andalas Padang, tentang "Pemeriksaan daya hambat ekstrak metanol daun Tristania subauriculata King terhadap pertumbuhan kuman Pseudomonas aeruginosa dan Staphylococcus aureus memberikan hasil sebagai berikut :

\section{Pemeriksaan daya hambat}

Tabe I Rata-rata diameter daerah bebas kuman Pseudomonas aeruginosa dan Staphylococcus aureus terhadap ekstrak metanol daun Tristania subauriculata King dalam berbagai konsentrasi.

\begin{tabular}{|c|c|c|}
\hline $\begin{array}{c}\text { Konsentrasi } \\
\text { ekstrak } \\
\text { Metanol (\% } \\
\text { b/v ) }\end{array}$ & \multicolumn{2}{|c|}{$\begin{array}{c}\text { Rata }- \text { rata diameter hambat } \\
\text { (mm) }\end{array}$} \\
\cline { 2 - 3 } & $\begin{array}{c}\boldsymbol{P} . \\
\text { aeruginosa }\end{array}$ & S. aureus \\
\hline $\mathbf{1 5}$ & 8,3 & 11,3 \\
\hline $\mathbf{3 0}$ & 10,3 & 13,7 \\
\hline $\mathbf{4 5}$ & 12 & 14,7 \\
\hline $\mathbf{6 0}$ & 13 & 16 \\
\hline
\end{tabular}

Dari tabel diatas terlihat bahwa ekstrak metanol daun Tristania subauriculata King dalam berbagai konsentrasi sudah mempunyai efek antibakterinya dimana pada konsentrasi $60 \%$ mempunyai efek antibakterinya yang sangat kuat (> 15 $\mathrm{mm}$ ) terutama untuk jenis S.aureus.

Untuk memperoleh gambaran yang lebih jelas tentang hubungan konsentrasi ekstrak dengan diameter hambat dari masing-masing bakteri dapat dilihat pada grafik berikut ini :

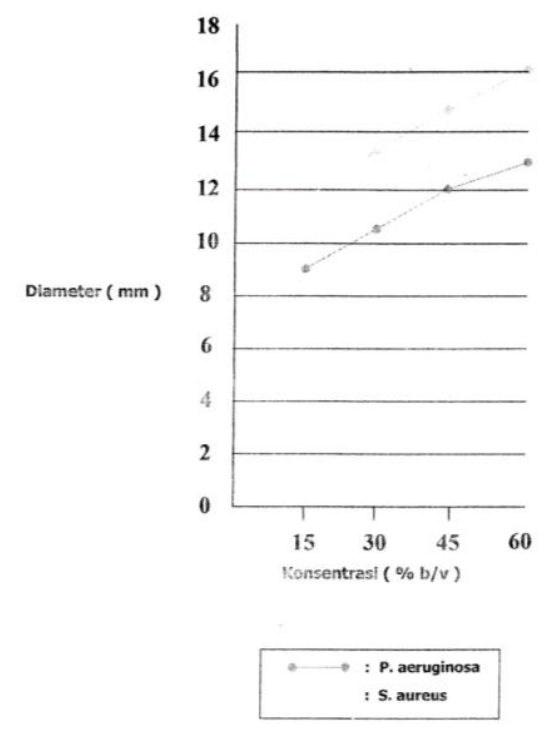

Gambar Diameter hambat ekstrak metanol daun Tristania subauriculata terhadap Pseudomonas aeruginosa

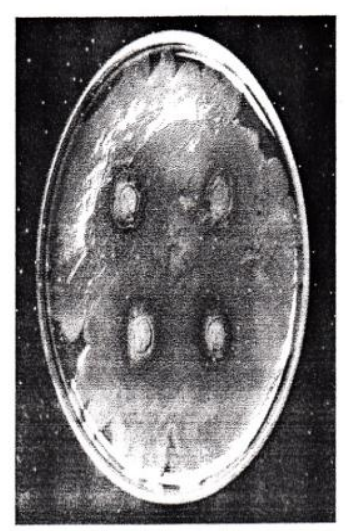




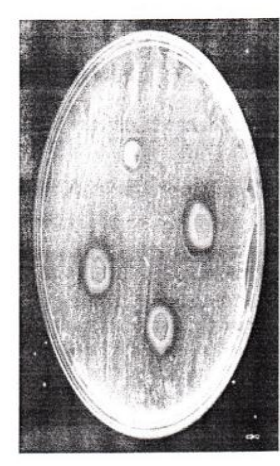

Gambar Diameter hambat ekstrak metanol daun Tristania subauriculata terhadap Staphylococcus aureus.

\section{PEMBAHASAN}

Dari gambar diatas terlihat bahwa ekstrak metanol daun Tristania subauriculata King memiliki daya hambat terhadap pertumbuhan Pseudomonas aeruginosa dan Staphylococcus aureus. Hal ini terbukti dengan adanya daerah bebas kuman (halo) disekeliling cakram yang berisi ekstrak metanol daun Tristania subauriculata King yang telah dilarutkan. Keadaan ini menjelaskan bahwa daun Tristania subauriculata King memiliki senyawa aktif yang bersifat sebagai anti bakteri.

Tabel 1 memberikan informasi bahwa ekstrak metanol daun Tristania subauriculata memberikan rata-rata diameter hambat yang bervariasi pada konsentrasi yang berbeda, dimana ratarata diameter hambat terbesar diberikan oleh ekstrak metanol daun Tristania subauriculata dengan konsentrasi $60 \%$ b/v yaitu $13 \mathrm{~mm}$ untuk Pseudomonas aeruginosa dan $16 \mathrm{~mm}$ untuk Sptaphylococcus aureus. Konsentrasi $45 \% \mathrm{~b} / \mathrm{v}$ memberikan rata-rata diameter hambat sebesar $12 \mathrm{~mm}, 30 \% \mathrm{~b} / \mathrm{v}$ sebesar $10,3 \mathrm{~mm}$ dan $15 \% \mathrm{~b} / \mathrm{v}$ sebesar 8,3 mm untuk Psedudomonas aeruginosa. Sementara itu, konsentrasi $45 \% \mathrm{~b} / \mathrm{v}$ memberikan rata-rata diameter hambat sebesar $14,7 \mathrm{~mm}, 30 \% \mathrm{~b} / \mathrm{v}$ sebesar 13,7 mm dan $15 \% \mathrm{~b} / \mathrm{v}$ sebesar 11,3\% untuk Staphylococcus aureus.

Keadaan ini menunjukkan bahwa semakin tinggi konsentrasi ekstrak metanol daun Trisna subauriculata King, maka akan semakin besar diameter hambatnya terhadap pertumbuhan Pseudomonas aeruginosa dan Staphylococcus aureus. Hal ini disebabkan karena senyawa aktif yang dikandungnya akan semakin banyak pula, seperti terlihat pada grafik. Berarti daya kerja ekstrak terhadap kuman dipengaruhi oleh konsentrasi ekstrak tersebut. Grafik ini juga memperlihatkan adanya perbedaan respon diantara kedua kuman, dimana Stapylococcus aureus lebih sensitive disbanding Staphylococcus aureus. Seperti yang diketahui, bakteri coccus memiliki dinding sel yang lebih tebal disbanding bakteri lainnya. Namun dari hasil penelitian didapatkan bahwa ekstrak metanol daun Tristania subauriculata King lebih efektif menghambat pertumbuhan Staphylococcus aureus, jadi diduga ekstrak metanol daun Tristania subauriculata King bersifat bakteriostatik dimana senyawa aktif daun ini mempengaruhi kerja ribosom sebagai pusat sintesa protein dan tidak mempengaruhi atau merusak dinding sel.
Adanya perbedaan pengaruh ekstrak metanol daun Tristania subauriculata King terhadap efek anti bakteri antara Pseudomonas aeruginosa dan Staphylococcus aureus banyak sedikitnya tentu dipengaruhi oleh perbedaan struktur morfologi dan biokimia kuman itu sendiri. Tidak tertutup kemungkinan adanya interaksi dengan senyawa atau molekul tertentu dalam tubuh mikroba yang dapat memperkuat atau mungkin menghambat efek anti bakteri dari daun Tristania subauriculata King. 
Analisa data hasil penelitian yang dilakukan dengan menggunakan Analisa Varian dalam rancangan acak lengkap, didapatkan adanya perbedaan yang nyata diantara perlakuan. Hal ini dapat dilihat pada Tabel dimana $\mathrm{F}$ hitung untuk Faktor A (perbedaan kuman) adalah 37,0293 sedangkan $F$ tabel untuk taraf kesalahan $5 \%$ adalah 4,49. Untuk faktor B (perbedaan kuman) juga didapatkan hasil yang berbeda nyata dimana $\mathrm{F}$ hitung adalah 46,4956 sedangkan $F$ tabel untuk taraf kesalahan 5\% adalah 3,24. Selanjutnya untuk mengetahui antara perlakuan yang mana yang berbeda nyata maka dilakukan uji dengan Duncan's Multiple Range Test pada taraf kesalahan 5\% terhadap faktor B.

\section{Kesimpulan}

Setelah melalui proses penelitian, perhitungan statistik dan pembahasan maka dapat disimpulkan :

1. Ekstrak metanol daun Tristania subauriculata King dapat menghambat pertumbuhan Pseudomonas aeruginosa dan Staphylococcus aureus.

2. Konsentrasi ekstrak metanol daun Tristania subauriculata King memiliki pengaruh terhadap efek anti bakterinya. Semakin tinggi konsentrasinya maka semakin besar diameter hambat yang dihasilkan.

3. Staphylococcus aureus lebih peka dibanding Pseudomonas aeruginosa terhadap ekstrak metanol daun Tristania subauriculata King.

\section{KEPUSTAKAAN}

1. Arbain,D.1999, Chemical Study of Sumatera Rubiaceae Plants, Proseeding International Seminar on Tropical Rainforest and
Their Utilization for Development, Padang.

2. Darwis, Dj, 2001, Teknik Isolasi dan Karakterisasi Senyawa Metabolit Sekunder, Makalah Workshop Peningkatan SDM Untuk Pemanfaatan SDA Hayati dan Rekayasa Bioteknologi, FMIPA Unand-Dikti Depdiknas, Padang.

3. Hadioetomo, R.S.Imas, 2008, Dasar-dasar Mikrobiologi,edisi pertama, Penerbit Universias Indonesia ( UI -Press) Jakarta.

4. Boyd, R.F. Marr,J.J.,1990, Medical Microbiology, Little Brown and Company.

5. Jawett, L.A. Melnick,J.L, Adelberg,e.a. (Setiawan,I), 1996, Mikrobiologi untuk Profesi Kesehatan, edisi 20, Penerbit Buku Kedokteran EGC, Jakarta.

6. Djuanda A, Hamzah, m, Aisah,S, 1994, Ilmu Penyakit Kulit dan Kelamin, edisi 2 Penerbit FKUI, Jakarta.

7. Hadioetomo, R.S, 1990, Mikrobiologi Dasar Dalam Praktek; Teknik dan Prosedur Dasar Laboratorium, edisi 2, PT.Gramedia Jakarta.

8. Arif, A, Sjamsudin, U, 1998, Farmakologi dan Terapi, edisi 4, Penerbit FKUI, Jakarta.

9. Agromedia, 2008, Buku Pintar Tanaman Obat, Cetakan pertama, Jakarta, PT. Agromedia Jakarta. 